\title{
DETERMINANTS OF FINANCIAL RESOURCES MOBILISATION OF INTEREST-FREE COOPERATIVE SOCIETIES IN ILORIN, KWARA STATE, NIGERIA
}

\author{
Abdulrazaq Taiye Jimoh \\ Department of Finance \\ University of Ilorin, Nigeria \\ E-mail: Jim0h.at1@unilorin.edu.ng
}

\begin{abstract}
Interest-free Cooperative society is introduced as a mirror of conventional cooperatives though on the principle of Islamic finance, to mobilise financial resources with the aim of promoting the socio-economic welfare of their members. There is however some restriction to the quantity of savings that could be mobilized. The study therefore assessed the determinants of savings mobilization in interest-free cooperative in Ilorin Kwara State. Data were collected with the use of questionnaire which was administered on 365 members of institution-based interest-free cooperative societies in Ilorin metropolis. Kaiser-Meyer-Olkin (KMO) and Cronbach's alpha tests were performed to establish the validity and reliability of the research instrument. Logistic regression analysis was conducted and it was found that mode of saving, credit administration, internal governance and member's awareness have positive effect on volume of savings mobilized and the effects are significant at 5\% and $1 \%$ level of significance. The study concluded that the mode of savings, credit administration, internal governance, and members awareness affect resources mobilization of Islamic cooperatives in Ilorin metropolis. Direct deduction of savings from salaries, higher level of transparency and accountability, sensitization campaign are recommended for effective and efficient financial resources mobilization in interest-free cooperative societies.
\end{abstract}

Keywords: Interest-free, Islamic, Financial Resources, Kwara, Savings.

\section{INTRODUCTION}

The role of cooperative societies in promoting economic welfare of people especially the cooperators cannot be over emphasized. In fact, the benefits of having such organizations flow to the entire economy through the multiplier effect. Cooperative societies perform such roles as promoting social welfare, education of members, employment generation, self-help and price advantage among others; and all of these will only be possible with availability of sufficient resources at the disposal of the societies. In other words, resources will have to be mobilized from various cooperators and other sources to meet the needs of cooperators and the society in general.

However, there are some limitations to the quantity of financial resources or funding that could be mobilized by the conventional co-operative societies due to some cultural factors like the perception of some cooperators and potential cooperators whose religious believes are in contrary to some practices within the conventional cooperatives. While such cooperators may restrict their participation to small savings of negligible amount, potential cooperators who hold contrary view and are completely excluded will be in search of alternative model for maximizing their social economic welfare. The only viable alternative to conventional 
cooperative model at the moment is the Islamic cooperative model which is built on principles Islamic law (Shariah) guiding business, financial and economic activities.

Non-Interest (Islamic) cooperative is an alternative cooperative model which makes the society to be more efficient with potential benefits to the cooperators and the general economy. The cooperative society that is based on Islamic principles of Shariah will be more efficient in its operations due to the fundamental principles of Islamic finance (free-interest, profit and loss sharing model, high uncertainty and speculation avoidance, and transparency) which will be combined with the values and principles of cooperative model.

The establishment of Islamic cooperative is principally on the concept of Shirkah Mufawadah in wherein cooperators contribute fund in the same portion as well as equally participate in managing the organization and the profit and loss are shared among the members (Nawai \& Shafii, 2017). This is but a theoretical definition which far from what is obtainable in practice particularly when it comes to cooperatives formation in places of work in which contributions are made based on financial capability of the cooperators. Also, it is not necessary in practice that all members should participate in the management of the society, though key decisions are made by members at members' annual meeting which represents the highest 'shuratic' forum in which all strategic decisions are made (Irfan \& Indah, 2011).

Like their conventional counterparts, Islamic cooperatives need financial resources to meet the social economic needs of their members who are in one way or the other contributes to the economic activities of the larger society. The financial resources required are usually mobilized through savings by members, charges for services such as loan application, and other business transactions involving the cooperative societies and their members. Continual funding and revenue from these sources require good operational performance of the societies which motivate the cooperators to save more and use them as intermediaries of business transactions. In Nigeria, Islamic cooperative is gradually evolving and with Muslim staff of some institutions particularly in the northern part of the country forming interest-free cooperative societies on the principle of Islamic jurisprudence. This type of Islamic cooperative may be tagged institutional based cooperative societies. Others are community-based. Institutional-based Islamic cooperatives are those societies whose members are basically the staff of the organization/institution in which the society is formed (Noibi \& Adewole, 2015). The community -based cooperatives on the other hands are all other Islamic cooperatives that are formed by people who come together in a community for promoting their welfares.

In the South-Western part of the country, the success recorded by Al-Hayat Relief Foundation, speaks volume of what a typical Islamic cooperative does to the socio-economic well-being of people. According to Noibi and Adewole (2015) the Foundation was established in 1997, with over 8000 members and 56 branches across Ogun, Oyo, Osun and Ondo States. Al-hayat has through its ranges of services like interest-free loan, benevolent loan, takaful insurance, and others impacted on the social and economic life of people, particularly its members (Noibi \& Adewole, 2015). Also, As-Salaam Development Foundation and University of Ibadan Muslim Co-operative Society founded in 1999 and 2002 respectively are some other examples of Islamic cooperatives whose members have benefited through acquisition of assets or properties (Jamiu, 2017).

In Kwara State, there are currently more than twenty registered Islamic cooperatives (Kwara State Ministry of Commerce \& Cooperative, 2019). Iman, Alburhan, Al-Hudah and At-taqwa are institutional-based societies that have been serving the socio-economic needs of their members for some years with numerous Shariah-compliant products. This implies that Islamic cooperative societies have potentials of meeting social economic needs of the people especially the cooperators if they are able to identify the various business opportunities within their localities. 
The evolving cooperatives must be well equipped with necessary resources to compete with the 'deep-rooted' conventional cooperatives. For favourable competition which is likely to be a major determinant of their survival in the long run, there is need for adequate financial resources at their disposal for their operations. Kareem, Raheem, Arije, and Olabode (2018) observed that interest-free cooperatives in Nigeria are still underfunded as adequate savings could not be mobilized from members. Inadequate funding makes members to satisfy with the operations of the societies and as a result they are discouraged to pump more funds as savings and investment to the cooperatives. Mohammad, Othman, and Mohammed (2013) stated that inadequate capital to carry on the business of such societies lead to inefficiencies. Other factors like weak structure, poor governance, lack of managerial skills, and lack of integrity among the management and the members of some cooperatives also contribute to inability of cooperatives including interest-free ones, to mobilize adequate financial resources for their operations (Mohammad et al., 2013).

Buttressing this, Jamiu (2017) stated that the Islamic cooperative would have long started in Nigeria had it been that the Muslim relief foundations of sixties have not been messed up by corrupt elements. In institutional-based cooperatives, members' savings are generally deducted at source. Failure to make deductions may give room to non-remittance or delay in loan repayment to the societies. Bad loan repayment habit and low level of knowledge or awareness about Islamic financial services on the part of the cooperators have also been identified as possible hindrances to financial resources mobilization in Islamic cooperative societies. Interest-free cooperatives must overcome all potential threats capable of putting them in bad light in the eyes of their members.

It is against this backdrop, that the study seeks to evaluate the factors affecting financial resources mobilization of Islamic cooperative societies in Ilorin, Kwara State, Nigeria. This becomes imperative as socio-economic welfare of members is promoted when adequate financial services are accessed by the members. This accessibility can only be possible when substantial financial resources are mobilized by the societies. Many empirical studies have identified various factors like income level, education, household size, age, marital status, and the factors have been found to be significant in determining performance of cooperatives via volume of savings mobilized (Akerele, Aihonsu, Ambali, \& Oshisanya, 2014; Sikirullahi, 2012; Noibi \& Adewole, 2015, Mustapha, Aremu, \& Brimah 2017). However, none of the studies on interest-free cooperatives have considered the effect factors like mode of saving, competition, credit administration, internal governance, level of members' awareness, which have been established in theoretical literature (Mmari \& Thinyane, 2019, Ngendakuriyo, 2014, Tanga, Lemma, \& Debebe, 2019, Mohammad et al., 2013 and Cheruiyot, Kimeli, \& Ogendo, 2012). This study is therefore conducted to examine the effects of these factors on volume of savings mobilized by non-interest (Islamic) cooperatives in Ilorin Metropolis.

Therefore, this study contributes to the existing body of knowledge on Islamic cooperative by assessing the effect of the identified factors on financial resources mobilization in interest-free cooperatives in Ilorin, Kwara State, Nigeria. This study will communicate some information about the factors affecting the flow of resources to those responsible for the affairs of Islamic cooperatives, and this will assist in improving the efforts being made on resources mobilization to meet socio-economic needs of members. Furthermore, the report of this work will serve as an educational material to members of cooperative societies whose knowledge and awareness levels are quite low when it comes to Islamic financial services. Perhaps, it will increase their propensity to save more for productive investment. Finally, findings of this work will serve as source of academic reference for future researchers, and students of knowledge in the field of Islamic finance. 


\section{LITERATURE REVIEW}

A cooperative, according to International Cooperative Alliance (ICA) (2010), is an autonomous association of persons unified voluntarily to meet their common economic, social and cultural needs through a jointly-owned and democratically controlled enterprise. Also, Kareem, Arigbabu, Akintaro, and Badmus (2012) viewed cooperative as a voluntary association of people who established a democratically controlled business entity, carrying on the business with operating cost that is contributed, capitalized and controlled by members and sharing rewards and risks in proportion to their participation, for the purpose of achieving a common socio-economic objective. It may also be defined as a privately formed society of likeminded people who come together to operate a savings and loan schemes among themselves with the aim of meeting their needs (Oluyombo, 2013).

This means that cooperative members are the main beneficiaries of the association as both the risk and benefits are shared among them. Not only that, ownership and control of the society lie with the cooperators. Nawai and Shafii (2018) defines Cooperative as an organization that is owned controlled and operated by a group of people who contribute capital and make decision on one-vote principle for the benefit of all members. As a way of summarizing the various attempts to appreciate the concept of cooperative, this study sees it as a voluntary association for the promotion of numerous socio-economic interests of members. Formation and operation of an association as a cooperative society is generally based on some fundamental principles. The International Cooperative Alliance (2006) identified seven principles of cooperative to include voluntary and open membership, democratic control, economic participation, autonomy and independence, education and training, cooperation and concern for community. Following these principles will enable the association to grow and contribute meaningfully to the members' economic welfare (Masuku, Masuku, \& Mutangira, 2016).

In meeting the economic and social needs of members, different types of cooperative societies evolved. Nwankwo, Ogbodo, and Ewuim (2016) mentioned consumer, producers, marketing, housing, transport, thrift and loan c as some of the different types of cooperative societies formed for fostering the interest of their respective members. Cooperative of farmers is another type of cooperative society that could be found in any farming community (Kareem et al., 2012). All of these are association formed on a conventional rules and principles. However, with the evolution of Islamic economics and finance, Islamic cooperatives sprang up and today, cooperatives may broadly be classified as conventional and Islamic cooperatives.

\section{Non-Interest (Islamic) Cooperative}

Islamic cooperative means a conversion of conventional cooperative to a form of association whose operations and approaches are in line with the principles of Islamic finance (Beik \& Purnamasari, 2011). According to Nawai and Shafii (2017), the concept of Shirkah Mufawadah is followed in establishing Islamic cooperatives. This means that all the members contribute and participate in the management of the cooperatives and profit is shared among members. Whatever business that the cooperative will engage in must followed the basic principles of shariah regarding Islamic finance. The principles of Shariah upon which Islamic finance is based include interest-free transaction, profit and loss sharing model of finance, avoidance of too much of uncertainty (gharar) and speculations (maysir), prohibited (haram) activities, and presence of real assets underlying all financial transactions (Franzoni \& Allali, 2018). Cooperatives that are built upon these principles of shariah are known as Islamic Cooperatives. Buchori (2009) outline the basic features of Islamic cooperative as ownership right of members on business capital, non-acceptability of riba-based transactions, presence of functional institution of Zakat, Sadaqah and Waqf, existence of profit motive in line with Shariah, acknowledgement of freedom of business and economic ventures and common rights. Another 
important feature of Islamic cooperative is the existence of strong cooperation among members. This is usually exhibited at the members' annual meeting which represents the highest 'shuratic' forum in which all strategic decisions are made (Beik \& Purnamasari, 2011).

\section{Islamic Versus Conventional Cooperatives}

Although Islamic cooperative is a mirror of conventional one in many aspects, except fundamentally for strict application of Islamic Law provisions (Shariah), researchers have identified some areas of differences between the two concepts. According to Hidayat (2004), objective, operational principle, source of profit, financing/lending perspective, and saving plans are the five main distinguishing features between conventional and Islamic cooperatives. Beik and Purnamasari (2011) provide a detailed explanation of these differences as follows:

- Objective: Islamic cooperative is driven by both profit and social motives while conventional cooperatives lay more emphasis on profit making;

- Operational principle: Islamic cooperative operates on the principles of Shariah and legal rules prevailing in the country, whereas conventional cooperative operates strictly on legal rules of the country;

- Sources of profit: profits of Islamic cooperative come usually, from Shariah-compliant transactions while for conventional cooperative, profit may be earned from interest charged on loan and other financial transactions;

- Perspective of financing/Lending: In Islamic cooperative, different contracts require different treatment as Shariah provisions will have to be considered for each contract. However, for conventional cooperative, interests are charged on all types of loans regardless of the nature of the contract;

- Saving Plans: In Islamic cooperative, apart from the usual saving schemes, there are other savings plans or schemes like Zakat pool of fund, which cannot be found with conventional cooperatives

\section{Islamic Cooperative Societies in Nigeria}

In Nigeria, cooperatives had been in existence long before independence, only for Islamic cooperative alternative to start springing up in the 1990s and early 2000 to meet the socioeconomic needs of Muslim population without compromising their religious believes (Sikirullahi, 2012). Nigerian Muslims constitute about 55\% of the country's population and this makes their yearning for Islamic financial products via cooperatives, a reasonable one (Sikirullahi, 2012).

Although the model of Islamic co-operative as it is being practiced in some other countries is comparatively new to Nigerian, many Islamic co-operative societies have been established by various Muslim communities either in well-established public and private organizations (institutions-based) or in communities that have zeal for Islamic co-operative and want to do away with interest bearing co-operative. It is however worthy of note that the concept is yet to be fully understood even by many Nigerian Muslims.

Despite the low understanding of many Muslims in the country, the cooperative model has been adopted in some States of the Federation including the FCT. There is Al-Hayat in Ogun State with branches in Oyo, Osun, Ondo, Lagos and Kwara States. As-Salaam Development Foundation and University of Ibadan Muslim community cooperative are in Ibadan. At the Federal Capital Territory, Abuja, there is the Islamic Crescent Co-operative Society (ICCS) Limited which is a home- grown Islamic co-operative model (Mohammed \& Hasan, 2009). In Kwara State, there are more than twenty Islamic cooperatives and the operations and achievements of the likes of Al-Burhan, Iman, At-taqwah, Al-hikmah muslim community and Al-Huda Islamic cooperative societies, in the area of socio-economic welfare of their members speak positive of Islamic cooperative in Nigeria. These societies, by 
promoting the welfare of their members are indirectly contributing to economic growth of the country.

Today in Nigeria, Islamic cooperatives like their conventional counterparts are contributing meaningful to the growth of national economies. Mustapha and Aremu (2017) state that the societies play significant roles in national socio-economic development of Nigeria through participation of their members in economic activities and social integration. Aside that, Islamic cooperatives facilitate a more equitable distribution of resources among its members and also provide employment opportunities to people. There is however the need for these cooperatives to operate efficiently for their activities to have positive effect on the macro economy. Efficient operations of Islamic cooperatives in the country require sourcing for adequate financial resources (funds) and ensure that the resources mobilized are effectively and efficiently utilized.

\section{Sources and application of funds (financial resources) in Islamic cooperatives}

Ajani and Adebayo (2018) discussed the various sources of financial resources available to Islamic cooperative in Nigeria as follows:

- Entrance fees: non-refundable fees collected from new entrants to the society as payment for forms, passbook, constitution and so on;

- Share capital: this is subscribed by every member either once or on installment basis at every sitting. The fund generated through this source is then used to conduct business operations and profit generated is shared at annual general meeting by members;

- Savings: savings are made to cooperatives by members so as to have access to loan when the need arises. Many cooperatives give double of the amount saved as loan to cooperator;

- Fines and levies: these are collected from any member who violates the rule of the cooperatives. Although there has been some arguments regarding the legality of this source of fund in Shariah, the claim of it being illegal was proved to be baseless due to the principle of Musalihul-mursilah. By this principle, any act or action which improves public welfare or interest but not mentioned or disapproved by Shariah will be deemed acceptable in Islamic Law.

- Sale of stationeries: this is another non-refundable fund which is generated through the sale of loan form or bond, and documents used to pay-in money into the Islamic cooperative's account (where applicable).

- Building fund: building fund is a refundable fixed amount payable by each member when there is a need to procure permanent office/residential building(s) for the cooperative.

- Administrative fund: this is normally subscribed for at every sitting for the management of the cooperatives. In some institutions-based cooperatives, administrative charges are deducted from monthly salary of members;

- Reserve: reserves are created by deducting certain percentage form members' savings or annual profit generated for some projects;

- Investment of Fund: sometimes, Islamic cooperatives may wish to invest on a particular project like hostel construction on campuses, members will then be asked to make contributions towards the construction;

- Net surplus: This is the excess of income over expenditure calculated based on the administrative and other funds like fines and levies, entrance fees, stationeries and others. Net surplus is the total income from these funds, less the total expenditure.

- Profit from businesses: this is the net gain from business activities of the cooperative.

Whenever funds are mobilized from the above sources, the next thing is to use the fund in the societies operations in the most efficient manner. Interest free loan is one of the ways for the 
application of financial resources mobilized by Islamic cooperatives (Ajani \& Adebayo, 2018). Apart from loan disbursement to members, there are many Shariah-compliant financial products on which the societies can invest through its business unit. Financial products that can be supplied by Islamic cooperatives may be classified as profit-loss sharing financing and nonprofit and loss sharing financing products (Hussain, Shahmoradi, \& Turk, 2015). Profit and loss sharing financing products include musharakah and mudarabah. While marabaha, ijarah, Salam and Istisna' are examples of non-profit and loss sharing financing products available at the business unit of any functional Islamic cooperative society. For better understanding, the following explanation is provided on each product.

Musharaka: this is a partnership business between the cooperatives and the user of the fund where the funding is provided by both parties for a project. Partners have right to participate the in business of the partnership. Profits are shared based on an pre-agreed ratio while sharing of losses is proportional to the capital contribution of each partner.

Mudarabah: This is an equity financing arrangement, where the cooperative supply fund to finance a business or project, the other party provides the skills and efforts to management the business. Profits are shared as agreed, but losses are to be borne by the financier. The only loss to the other party (mudarib) is the effort put in the business (Rahman, 2018).

Murabahah: Mansour and Sa'adeh (2016) state that in a murabahah transaction, cooperative buys the item required by the user and sells it at a profit to the user with the payment deferred to a date agreed by the parties. The payment is normally made in instalments.

Ijarah: This is a lease arrangement between the financier and the user of the asset (ICAN, 2014)

Salam is transaction for a delivery to be made at a future date in exchange for immediate settlement of payment.

Istisna': Istisna' is an agreement between the buyer and seller wherein a commodity is transacted before the production of such commodity. According to (Hussain et al., 2015) in istisna' nothing is exchanged on the spot or at the time of contracting.

\section{Financial Resources Mobilization and Determinants}

In cooperative societies whether conventional or Islamic, funds or savings are mobilized to meet the needs of members. Sufficiency or otherwise of such savings depends on some factors many of which have been discussed by researchers. Mode of savings, competition, issues of administration of credit, employment, inflation, members' awareness level, and governance issues are some of the factors identified by researchers' and each of the factors are presented as follows:

Mode of saving: Ngendakuriyo (2014) opined that individuals save their money using different modes of savings. This was also the view of Cheruiyot et al. (2012) which stated that types of savings available determine savings mobilization of cooperative institutions. The implication is that funds are mobilized by cooperative societies via different saving plans or schemes and members should be free to select any of the schemes. The freedom gives them a sense of belonging which serves as encouragement to save more the societies. Also, availability of different savings plans means funds will come in through a variety of sources. 
Credit administration: Administering credits to members features issues like loan processing time, poor repayment habit, and financial liquidity of the cooperative. According to Mmari and Thinyane (2019), the longer the time period between application and disbursement, the more discouraged are members regarding the operation of the cooperative. When members are not happy with the activities of the society, they see no reason to increase their savings. On the issue of loan repayment habit of borrowing members, cooperatives will have adequate resources to meet the needs of other members when the disbursed loans are repaid as scheduled. Most institutions-based cooperative adopt the method of direct deduction from salary as a way of curbing poor repayment. It should also be noted that liquidity of the society may be affected when loans are not repaid as and when due.

Competition: Islamic cooperative societies will have to compete with conventional ones for both membership and savings mobilization. This is because the size of membership determines to a large extent, the fund mobilization as well as capital adequacy of such societies (Mmari \& Thinyane, 2019).

Awareness level: Tanga et al. (2019) state that the level of knowledge and awareness of members on the business activities of cooperatives determine their participation in the cooperatives through saving. For example, Islamic cooperatives have some Shariah-compliant financial products on the principle of profit and loss sharing. If members are adequately informed about the availability of such opportunities, chances are there that they will increase their savings for investment purposes.

Employment/Occupation: Tanga et al. (2019) Cooperatives whose members are employees on payroll of an organization tends to have more financial resources. This is because, in most cases, savings will be done by direct deduction from their salaries. In the same vein, loans from members are likely to be repaid via same medium. This is usually possible with institutionbased cooperative societies.

Internal governance: this has to do with poor governance, poor internal control, lack of managerial talent, lack of integrity among the management of cooperatives (Mohammad et al., 2013). All of these contribute to inefficiencies in cooperative societies and as a result members are discouraged from putting more funds in inefficient and corruption-ridden organisations.

\section{Theoretical Discussion}

This study is underpinned by Keynesian theory of income, and Katona's theory of Saving According to Byusa (2016), the theory of absolute income was propounded by Keynes (1936) and held that saving increases when income rises, as more fund will be available after consumption and meeting the basic needs of individuals or household. The theory holds further that if the growth of income will result in growing consumption but at a smaller rate. The implication is that savings will grow more as the difference between the increases in income and that of consumption will be saved (Bala, 2015). The Keynesian theory views the ability of an individual to save as a function of his/her income. That is, the proponents of the theory believe that when income level of an individual or household changes positively, the upward movement tends to bring about increase in the level of savings. It can be deduced from this theoretical explanation that if a person has more source of income or an increased level of income, the person's consumption patterns will change. Such a person will however save some of his income since he will not ordinarily spend all his income on consumption expenditures. However, the theory of absolute income is plagued by the simplistic assumption of income as the determinant of savings. The theory ignored factors like the willingness of the income earner 
to save some of his income. It is on this ground that Katona (1975) developed his hypothesis on savings. The Katona's theory of saving, built on the weaknesses of the Keynesian theory of absolute income, state that simply having money left over after expenditures on necessities does not translate into saving but rather willingness to save is critical. That is, a person who has ability to save due to his level of income still need to decide whether or not to save, and making such decision requires some degree of willingness (Byrusa, 2016). The willingness to save by any individual is determined by several factors including the mode of savings, available saving products and the level of awareness of the savers on the available savings plans or products. Buttressing these points, Ngendakuriyo (2014) opined that individuals save their money using different modes of savings. In other words, people save more when they are free to select different means of saving.

This theory made it clear that numerous factors affect the mobilization of financial resources via savings from individual members of the cooperatives. For the purpose of the study, factors like mode of savings, credit administration, internal governance and awareness of members on the products available are likely to influence the ability of Islamic cooperatives to mobilize adequate financial resources through savings.

\section{Empirical Review}

Several empirical studies have been conducted on determinants of financial resources (savings) mobilization of cooperative societies. Karagu and Okibo (2014) investigated the factors influencing performance of savings and credit cooperatives in Kenya. Descriptive design was employed and data were collected from members of thirty selected cooperatives in Nairobi County via questionnaire. The study found that misappropriation of funds, loan repayment default, members' withdrawal, and investment decisions have significant effect on performance of Savings and Credit cooperatives via savings mobilization. Mpiira, Kiiza, Katungi, Tabuti, Staver, and Tushemereirwe (2014) studied the determinants of savings mobilisation of Savings and Credit cooperatives in Uganda. Primary household data was collected with structured questionnaire and analyzed with Weighted Least Squares (WLS) regression technique. The study found that volume of savings decreased with increase in level of education, trading activities of members, and more dependent relatives, while increase in income level, credit accessibility increased the savings mobilization of the societies.

Njogu and Omagwa (2018) evaluated the relationship between credit (loan) administration and performance of cooperative societies in Kenya. Using correlation analysis, the study found positive relationship between credit administration and savings of the cooperatives. On internal governance of cooperatives, Mwanja, Marangu, Wanjere, and Thuo (2014) assessed the extent to which transparency and accountability as governance proxies affect growth of deposit (savings) and membership of cooperative societies in Kakamega, County, Kenya. Data were collected with questionnaire and analysed using both descriptive and inferential statistics. The study found that transparency and accountability in the handling of cooperative activities have positive impact on the growth of savings (deposit) and membership of the societies.

In another study, Sebhatu (2012) examined the saving behavior of cooperative members in Ethiopia and data was obtained from randomly selected 120 savers in 8 cooperative societies. Regression analysis was conducted and result showed that gender, household income level, amount of loan borrowed, and year (length) of cooperative membership have positive and significant effect on savings of members to the cooperatives. Similarly, Nwakwo, Ewuim, and Asoya (2013) assessed the determinants of saving behavior of cooperative members in Anabra, Nigeria. Data were collected from a sample of 195 randomly selected members of credit cooperatives and analyzed using descriptive statistical tools and multiple regression model estimation. Results indicate that age, education, family size, length of cooperative membership 
have positive and significant effects on savings. Whereas, income level, was found to have had negative effect on savings mobilization of cooperative societies.

Specifically, studies on determinants of financial resources mobilization in interest-free cooperatives are scanty though there are empirical works on the role of interest-free cooperatives and service quality and customer satisfaction in cooperative societies. Some the existing studies are reviewed. Riwajanti (2019) studied assessed Islamic cooperative performance in Malang, Indonesia. Primary data were collected via interview method and results of thematic analysis showed that the level of awareness about Islamic cooperative is quite low even at Mosque level, for that reason, sufficient funds could not be mobilized to meet economic needs of people at community level. This implies that level of awareness is a major factor affecting mobilization of savings in Islamic cooperative society in Indonesia.

Also, Fisol, Abdulhamid, and Cheumar (2018) assessed the factors determining the usage of Islamic cooperatives financial products in Thailand. Data were collected with questionnaire on the relationship of attitude, subjective norms, and level of knowledge and religiosity with usage of Islamic financial products of cooperatives. Pearson Correlation Analysis was conducted after carrying out of reliability test on the data collection instrument with the use of Cronbach's Alpha analysis. The study found a significant relationship between level of knowledge and usage of financial product of Islamic cooperative. That is, the level of knowledge of cooperative members affects the usage of products in Islamic cooperative. In other words, mobilization of savings via different Shariah-compliant products was affected by the level of awareness.

Bukhari (2013) study the utilization of Islamic financial product by Islamic cooperative societies in meeting the needs of their members in Ilorin, Kwara State. Data for the study were collected using questionnaire and interview methods. Descriptive analysis was conducted through the use of simple percentage analysis and the study found that introduction of Shariahcompliant Islamic product has had significant impact on the effort of Islamic cooperatives to meet socio-economic needs of their members. Also, Noibi and Adewole (2015) assessed the socio-economic impact of interest-free (Islamic) cooperative on the welfare of members. The study was a case analysis and data were obtained from members of the case organization via questionnaire and interview. It was found the case organization promotes socio-economic welfare of its members with provision of different interest-free financial products.

In a more recent study, Mustapha, Aremu, and Brimah (2017) made a comparative analysis of interest-based and interest-free cooperative societies in Ilorin Emirate. The study was specifically on the quality of service and satisfaction of customer (members) of the two types of cooperative societies. A combination of stratified and convenience sampling techniques to select 180 target respondents from the study area. Independent t-test and regression analysis were employed as analytical technique. The study found that a significant difference exists between service quality and satisfaction of interest-based and interest-free cooperative and their conclusion favours interest-free cooperatives.

Other studies on Islamic cooperatives focused on the cooperatives' role in financing small business. Beik and Purnamasari (2011) examined the financing activities of Islamic cooperatives and their impact on small scale businesses in Indonesia. A survey on 100 micro and small scale entrepreneurs was conducted on. Likert scale and path analysis were employed as analytical tools. The study found that financing procedures and financing impact positively on business of small scale entrepreneurs in the country. The study also found that administrative cost and education (awareness) level significant factors affecting access of the businesses to the cooperative finance.

Another dimension of study is the comparative analysis of interest-based and interestfree institutions like cooperative societies. Ali, Ali, and Khwaja (2013) conducted a study on the comparison of Islamic and Conventional services with Riba (interest) services in Peshawar 
region of Pakistan and found that the services of Islamic financial institution are far better than conventional services providers particularly when the issue of riba (interest) is considered. In the like manner, Shiraj, Shameen, and Nawas (2014) assessed Islamic and conventional financial products with emphasis on service quality and customer satisfaction in Sri Lanka. The study found that customers of Islamic financial services providers (including cooperative) derived more satisfaction in the quality of services being provided as compared with conventional ones.

It is clear from the empirical review that very few studies exist on interest-free cooperatives and there is dearth of research in the area of financial resources mobilisation and its determinants. Research works on conventional cooperatives have considered factors like income level, age, education, length of membership, and family size (Karagu \& Okibo, 2014, Mpiira et al., 2014, Sebhatu, 2012, Nwakwo et al., 2013). Other factors such as mode of savings, level of members' awareness, competition, and internal governance, which have been identified in theoretical literature, are largely ignored by studies on both conventional and Islamic cooperatives. There are about two empirical studies that included level of members' awareness and governance issues (misappropriation of funds) as part of determinants of financial resources mobilization (Karagu \& Okibo, 2014)

This study therefore fills the gap in literature by examining the impact of the identified factors on the financial resources mobilization of interest-free cooperatives. The study will also serve as extend the frontier of knowledge by pioneering the empirical work in the area of determinants of financial resources mobilisation in interest-free cooperatives in Nigeria.

\section{METHOD}

This research was designed to capture the factors influencing financial resources mobilization of interest-free cooperatives in Ilorin Metropolis. Survey research method was used to gather information from respondents concerning their perceptions on certain aspects of financial resources mobilization.

The study population consists of 4195 members of five institution-based interest-free cooperatives in Ilorin Metropolis. A sample of 365 was chosen using Yaro-Yammani's sampling model. This implies that the sample for this study consist of 365 respondents that were selected across the cooperatives in proportion to the membership size of each cooperatives. In other words, systematic sampling technique was adopted (see Appendix 2).

Data used for this study is primary in nature obtained through questionnaire administration. To ensure content validity of the instrument used for the study, copies were given to academic and professional colleagues in finance. Their useful recommendations were incorporated into the final draft of the questionnaire. The research questions were answered and hypotheses were tested by estimating an ordinal logistic regression model which describes the relationship between the explained variable and a set of explanatory variables rated on a 5 point Likert-scale response options of strongly agree (SA), agree (A), neutral (N) disagree (D) and strongly disagree (SD) with weights of 5, 4, 3, 2 and 1, respectively. This was achieved with the aid of STATA (version 12) statistical package.

The relationship between financial resources mobilisation and its determinants as established in conceptual literature is expressed mathematically as:

Financial Resources Mobilisation $=f$ (Factors Affecting financial Resources Mobilisation of Interest-free cooperatives)

This is expressed econometrically as follows:

$$
\operatorname{VolSav}=\beta_{0}+\beta_{1} M \operatorname{Sav}_{i 1}+\beta_{2} \operatorname{Comp}_{i 2}+\beta_{3} \operatorname{CRAd} d_{i 3}+\beta_{4} \operatorname{InGov}_{i 4}+\beta_{5} M A W R_{i 5}+\mu_{i}
$$


Where:

VolSav $=$ volume of members savings

MSav $=$ modes of savings

Comp $=$ competition with conventional cooperatives

CRAd $=$ credit administration

InGov= Internal governance

MAWR = members level of awareness about the products and services of cooperatives $\mu=$ error term

Since the above model is based on perceptions, its general probability function is appropriate and thus specified as follows:

$$
\begin{aligned}
& L_{i}=\operatorname{In}\left(\frac{P_{i}}{1-P_{i}}\right)=\beta_{1} X_{1}+\beta_{2} X_{2}+\ldots \beta_{n} X_{n} \\
& P i\left(Y=j \mid X_{1}, X_{2}, \ldots X_{n}\right)=f\left(\beta_{1} X_{1}+\beta_{n} X_{n}\right) \\
& P i\left(Y=j \mid X_{1}, X_{2}, \ldots X_{n}\right)=\frac{1}{1+e^{-\left(\beta_{1} X_{1}+\beta_{2 X_{2}}+\cdots \cdot \beta_{n X_{n}}\right)}}
\end{aligned}
$$

Where Li $=$ Response variable, Logit, Log of the odds that the event occurs

$\operatorname{Pr}=$ Probability of event occurring, $\mathrm{j}=$ Ordinal response ranging from $1,2, \ldots \mathrm{j}$

$\mathrm{e}=$ exponential function

$\mathrm{X}_{1}, \mathrm{X}_{2}, \ldots \mathrm{X}_{\mathrm{n}}=$ Explanatory variables. (Gujarati, 2004)

Apriori expectation:

Apriori expectation:

$\beta_{0}>0, \beta_{1}>0, \beta_{2}<0, \beta_{3}>0, \beta_{4}>0, \beta_{5}>0$

The implication is that positive effect is expected from all the explanatory variables except competition.

\section{RESULT}

Results of data analysis are presented in tables 1 to 4 and discussed as follows.

Table 1. Questionnaire Retrieval Analysis

\begin{tabular}{|l|c|c|}
\hline Questionnaire & Frequency & Percentage (\%) \\
\hline Returned copies & 347 & 95 \\
\hline Wrongly filed/unreturned copies & 18 & 5 \\
\hline Copies administered & 365 & 100 \\
\hline
\end{tabular}

Source: Field Survey (2019)

Table 1 presents Questionnaire retrieval analysis. From the table, three hundred and sixty five (365) copies of questionnaire were administered, out of which one three hundred and forty seven (347) copies representing 95\% were returned and used the analysis. The remaining 18 copies were wrongly filled/ unreturned and not used for the study. 
Table 2. Validity Tests

\begin{tabular}{|l|l|l|l|l|}
\hline \multirow{2}{*}{ Variables } & \multirow{4}{*}{} & \multicolumn{3}{|c|}{ Bartlett's Test of Sphericity } \\
\cline { 3 - 5 } & \multirow{2}{*}{ KMO } & Chi-square & Df & P-value \\
\hline Operational Questions & .602 & 754.017 & 164 & 0.001 \\
\hline
\end{tabular}

Source: Author's computation (2019)

As regards the construct validity in term of convergent validity, confirmatory factor analysis was performed. Kaiser-Meyer-Olkin (KMO) and Bartlett's tests were performed. The $\mathrm{KMO}$ is a measure of sampling adequacy and ranges between 0 and 1. The Barlett's test of sphericity value should be significant (the Sig. value should be less than or equal to 0.05 ). The results of this test are shown in table 2. This shows that all measurement items of each sample are significant at level 0.01 based on the Barlett's test of sphericity. The KMO value of each construct is 0.602 . The implication of this result is that the measurement scales used in this study are valid.

Table 3. Reliability Statistics

\begin{tabular}{|l|l|l|}
\hline Variables & Cronbach's Alpha & No. of Items \\
\hline Mode of Savings & 0.84 & 3 \\
\hline Competition & 0.79 & 3 \\
\hline Credit Administration & 0.74 & 3 \\
\hline Internal Governance & 0.81 & 3 \\
\hline Level of Awareness & 0.76 & 3 \\
\hline
\end{tabular}

Source: Author's computation (2019)

In Table 3, result of reliability analysis is presented which indicate the consistency of the instrument in measuring the variables of the study. The Cronbach's alpha test of each factor influencing financial resources mobilisation shows satisfactory level of reliability with Cronbach's alpha values higher than the minimum threshold (Cronbach's alpha $>.70$ ).

Table 4. Estimates of Ordered Logit Regression and the Marginal Effect

\begin{tabular}{|l|l|l|}
\hline \multirow{2}{*}{ INDEPENDENT VARIABLES } & \multicolumn{2}{|l|}{ Dependent variable: Volume of Savings } \\
\cline { 2 - 3 } & $\begin{array}{l}\text { coefficients of } \\
\text { ordered logit }\end{array}$ & $\begin{array}{l}\text { Marginal effect after } \\
\text { ordered logit }\end{array}$ \\
\cline { 2 - 3 } & $(1)$ & $(2)$ \\
\hline MSav & $0.69^{* *}$ & $2.93^{* *}$ \\
\hline & $(0.25)$ & $(0.03)$ \\
\hline Comp & $-0.72^{* * *}$ & $-0.10^{* * *}$ \\
\hline & $(0.20)$ & $(0.03)$ \\
\hline CRad & $0.77^{*}$ & $0.27 *$ \\
\hline & $(0.25)$ & $(0.03)$ \\
\hline InGov & $0.19 * *$ & $0.28^{* *}$ \\
\hline
\end{tabular}




\begin{tabular}{|l|l|l|}
\hline & $(0.04)$ & $(0.05)$ \\
\hline MAWR & $0.56^{* * *}$ & $0.083^{* * *}$ \\
\hline Constant cut1 & $(0.13)$ & $(0.020)$ \\
\hline & -0.0038 & -0.0053 \\
\hline Constant cut2 & $(0.0089)$ & $(0.0084)$ \\
\hline & 2.7254 & \\
\hline Constant cut3 & $(2.8850)$ & \\
\hline & $8.4512^{* * *}$ & \\
\hline Observations & $(2.9945)$ & \\
\hline Fitness statistics & 347 & 347 \\
\hline Probability of fitness statistics & 80.500 & \\
\hline
\end{tabular}

Source: Author's Computation (2019).

Standard errors in parentheses $* * * \mathrm{p}<0.01, * * \mathrm{p}<0.05, * \mathrm{p}<0.1$ denotes $1 \%, 5 \%, 10 \%$ level of significance respectively.

Table 4 shows the Ordered Logit Regression estimates for the determinants of financial resources mobilization of interest-free (Islamic) cooperatives in Ilorin metropolis. Columns 1 and 2 contain the ordered logistic Regression and its marginal effect respectively. The coefficient estimates of the regressions are used to examine the nature of relationship and significance of the independent variables while the marginal effect is used to evaluate the extent (magnitude or size) of impact of the independent variables on the dependent variable.

In the model, volume of saving (proxy for financial resources mobilization) is the dependent variable while mode of saving, competition, credit administration, internal governance and members' awareness are independent variables financial resources mobilization.

The result of the ordered logit revealed that mode of saving (MSav), Credit administration (CRAd), internal governance (InGov) and member's awareness (MAWR) are positively related to the volume of Saving (VolSav). The relationship is depicted in Table 4 with positive coefficients of the variables as $0.69,0.77,0.19$ and 0.56 for mode of savings, credit administration, internal governance and awareness level respectively. The effects of mode of saving and internal governance are found to be significant at 5\%, whereas, the effect of credit administration on savings mobilization is significant only at $10 \%$ level. Awareness of members has significant effect on the mobilization of savings at $1 \%$ level of significance. This implies that mobilization of resources in form of savings will increase with any positive change in modes of savings, credit administration, and members' awareness level in relation to the services of cooperatives.

However, competition (Comp) is inversely correlated with the dependent variable (volume of saving). An increase in competition tends to result in reduced savings mobilization. This is indicated by the coefficient value of -0.72 . The relationship is also significant at $1 \%$ level.

The coefficients of the cut parameters are used to examine the essence of the response categories (strongly agreed, agreed, undecided disagreed and strongly disagreed). If the cut values are statistically significant, the categories are maintained in the interpretation otherwise insignificant categories are collapsed to for a category. In Table 4, all the constant cut values except cut 3 are statistically insignificant therefore we can collapse all other categories apart from category 3 and 4 . This means the responses undecided disagreed and strongly disagreed are not being distinguished by the respondents but strongly agreed, agreed are clearly defined. 
To examine the goodness of fit of the model, the log likelihood chi-square statistics of the model is reported. The fitness statistics of the ordered logit is 80.500 with the P-value 0.0000 testifies to the overall significance of the model at $5 \%$ level of significance.

\section{DISCUSSION}

The results of analysis show that mode of savings have positive and significant effect on volume of savings mobilized by interest free cooperative societies. Mode of savings means the method of depositing funds as savings to the cooperative. While some members will make personal deposit through the bank or direct to the cooperative, others would prefer deduction from source. In most cases, direct deductions result in more savings to the cooperatives as personal deposit may be affected by some extraneous factors. Also members might be given opportunity to have special savings with the cooperative which consequently improve the financial resources mobilization of such cooperative. The finding is in line with Cheruiyot et al. (2012) which observed that availability of different mode of savings to cooperative members might be a major determinant of resources mobilization.

The relationship between credit administration and volume of savings mobilized was also found to be significantly positive. This may be due to timely attention and treatment being given to loan request. Individuals are likely to glue more to such a society where their demands are promptly attended to. They may be encouraged to increase their savings with the cooperative and /or attract more people to join the society. Also adequate monitoring of repayment will reduce the default risk and boost loanable savings. Similar result has been reported Njogu and Omagwa (2018) on the effect of credit administration on savings in Kenya. Concerning governance issues, internal governance is positively related to savings and the relationship may be linked to the satisfaction derived by members in the ways and manners by cooperatives' activities are being handled by the management. For instance, if the executives are transparent such that cases of fraud and unethical practices are minimized, members' confidence will be boosted with consequential effect on the mobilized funds via savings. This is also in consonance with earlier report of Mwanja et al. (2014) that the levels of transparency and accountability in the handling of cooperative affairs have positive impact on the growth of savings (deposit) and membership of the societies.

Similarly, level of members' awareness on the Shariah-compliant products affects financial resources mobilization of the cooperatives. Adequate knowledge about the availability of some these products may motivate members to increase their investment through savings. Riwajanti (2019) reported that the lower level of awareness has been the major hindrance for savings mobilization in Indonesia. The finding of Riwajanti (2019) was in agreement with Faisol et al. (2018) as well as the finding of this current study.

Conversely, the study found that competition has negative impact on volume of saving mobilized by interest-free cooperative. Islamic cooperatives exist alongside the conventional cooperatives and thus compete with one another for membership as well as resources mobilization. As Islamic cooperative is still at evolutionary stage, the finding suggested that competition with conventional counterparts has not yielded favourable results in terms of volume of savings mobilized. All of these confirm the Katonia theory of savings that other factors aside income determines savings.

This study has evaluated the factors affecting financial resources mobilization of interest-free cooperatives within the framework of Katonia theory of saving. Results of analysis show positive and significant effects of the factors, with the exception of competition, on volume of savings of the cooperatives. It is therefore concluded that mode of saving, credit administration, internal governance, level of members' awareness influence financial resources mobilization of interest-free (Islamic) cooperative societies in Ilorin metropolis. Based on this conclusion, the study recommends that interest-free cooperative should mandate direct 
deduction of savings and loan repayment to curb any unwillingness to save and increase the level of financial resources mobilized. Also, there is need for high level of transparency and accountability on the part of those responsible for the management of Islamic cooperatives as this will go a long way to control tendencies for sharp practices within the societies. Furthermore, awareness campaign should from time to time be organized for members to get them informed about the activities, products and opportunities that are in stock for members of such cooperatives. This will give competitive advantage to the cooperative in terms of membership and resources mobilizations.

\section{REFERENCES}

Ajani, M.A.A., \& Adebayo, R.I. (2018). An examination of the sources and expenditures of funds in the Islamic cooperative societies in Nigeria. Ilorin Journal of Religious Studies, (IJOURELS), 8(2), 35-50.

Akerele, E.O., Aihonsu, J.O.Y., Ambali, O.I., \& Oshisanya, K.P. (2014). Factors affecting loan repayment performance among members of cooperative thrift and credit society in Yewa North local government area, Ogun State, Nigeria. Greener Journal of Agricultural Sciences, 4(6), 238-244

Ali, L., Ali, A., \& Khwaja, H. (2013). Comparison of Islamic and Conventional Banking on the Basis of Riba(interest) Services: A case study of Peshawar Region. International Review of Management and Business Research, 2(3), 23-31.

Bala, R.M. (2015). A comparative analysis of Keynes and Friedman consumption models for Romanian case. International Conference on Trends in Business and Economics (ICTBE'15) May 29-30, 2015 London (UK)

Beik, I., \& Purnamasari, I. (2011). Role of Islamic cooperatives in financing micro and small scale entrepreneurs in Indonesia: Case Study of KOSPIN Jasa Syariah Pekalongan. Paper presented at the Eight International Conference on Islamic Economics and Finance, organized by Qatar Faculty of Islamic Studies and the Qatar Foundation on 19th -21th December 2011, Doha Qatar.

Buchori, N.S. (2009). Koperasi Syariah. East Java, Indonesia: Mashun.

Bukhari, S. (2013). An inquiry into the islamic cooperative societies in Ilorin Vis-à-vis their utilization of Islamic financial products. Journal of Islamic Banking and Finance, 30(4), 73-83.

Cheruiyot, T. K., Kimeli, C.M., \& Ogendo, S.M. (2012). Effect of savings and credit cooperative societies strategies on member's savings mobilization in Nairobi, Kenya. International Journal of Business and Commerce, 1(11), 40-63.

Fisol, M. W., Abdulhamid, M., \& Cheumar, M. (2018).Determinant factors muslim's intention to use islamic cooperative products and services: A case study in Southern Thailand. The $3^{\text {rd }}$ CHREST International Conference.

Franzoni, S., \& Allali, A. A. (2018). Principles of Islamic finance and principles of corporate social responsibility: What Convergence? Sustainability, 10(637), 1-11 
Hidayat, Y. (2004). Efektivitas Pembiayaan Pola Bagi Hasil Pada Batul Maal wat Tamwil (BMT) Hubbul Wathon, Kecamatan Cilamaya, Kabupaten Karawang, Jawa Barat [Script]. Bogor: Bogor Agricultural University.

Hussain, M., Shahmoradi, A., \& Turk, R. (2015). An overview of Islamic finance. IMF Working Paper, 15/120.

ICAN. (2014). Strategic Financial Management. Study Text: Emile Woolf International: China.

International Cooperative Alliance. (2010). Co-operative identity, values \& principles. International Cooperative Alliance. Retrieved from https://ica.coop/en/whats-coop/cooperative-identity-values-principles

International Cooperative Alliance. (2006). International cooperative alliance, Department for International Development (DFID). Retrieved from http://www.ica.coop

Jamiu, F.O. (2017). Contributions of Islamic co-operative societies to Muslims in Yorubaland (South-Western Nigeria). Journal of Islamic Social Sciences and Humanities, 11, 5163

Kareem, R.O., Arigbabu, Y.D., Akintaro, J. A., \& Badmus, M.A. (2012). The impact of cooperative society on capital formation (A case study of Temidere Co-operative and Thrift Society, Ijebu- Ode, Ogun State, Nigeria. Global Journal of Science Frontier Research, 12(11), 17-29.

Kareem, R., Raheem, K., Arije, R., \& Olabode, B. (2018). Impact of conventional and Islamic cooperative societies on poverty alleviation. A case study of neuro-psychiatric hospital, Aro, Abeokuta, Ogun State, Nigeria. Journal of Sustainable Development in Africa, 20(4), 78-93

Katona, G. (1975). Psychological economics. New York: Elsevier.

Kwara State Ministry of Commerce and Cooperative. (2019). List of registered interest-free cooperatives in Kwara State (Extract).

Mansour, I., \& Sa'adeh, Y. (2016). Evaluating murabaha in Islamic banks. International Journal for Innovation Education and Research, 4(6), 185-190

Masuku, T.A., Masuku, M.B., \& Mutangira, J.P.B. (2016). Performance of multi-purpose cooperatives in the Shiselweni Region of Swaziland. International Journal of Sustainable Agricultural Research, 3(4), 58-71.

Mmari, G.A., \& Thinyane, L.C. (2019). Analysis of factors influencing financial performance of savings and credit co-operative societies in Lesotho: Evidence from Maseru District. International Journal of Financial Research, 10(2), 121-136

Mohamad, M., Othman, I. W., \& Mohamed, A. (2013). Accountability Issues and Challenges: The Scenario for Malaysian Cooperative Movement. International Journal of Economics and Management Engineering, 7(6), 1503-1508. 
Mustapha, Y.I., Aremu, M.A., \& Brimah, A.N. (2017). Comparative analysis of service quality and customers' satisfaction of interest and non-interest based cooperative societies in Ilorin emirate. Jordan Journal of Business Administration, 13(4), 537-556.

Mwanja, B. K., Marangu, W.N., Wanjere, D.M., \& Thuo, K.J. (2014). Effect of corporate governance on performance of savings and credit co-operative societies in Kakamega County. European Journal of Business and Management, 6(30), 123-136

Nawai, N., \& Shafii, Z. (2017). Understanding Islamic cooperatives mechanisms for the accessibility promotion of Islamic finance in Malaysia. Journal of Islamic Philanthropy \& Social Finance (JIPSF), 1(1), 1-13

Ngendakuriyo, F. (2014).Household saving mobilization across EAC Countries. An exploratory analysis in financial sector development and regionalization project. Tanzania: Arusha.

Njogu, A. M., \& Omagwa, J. (2018). Loan administration and financial performance of savings and credit co-operative societies in Kirinyaga County, Kenya. International Journal of Current Aspects in Finance, 4(2), 55-70.

Noibi, M.A., \& Adewole, A.O. (2015). The socio-economic impact of Al-Hayat Relief Foundation on Muslims in Abeokuta, Nigeria. The Journal of Religions, 11, 97-118

Nwankwo, F., Ogbodo, O. C., \& Ewuim, N. (2016). Effect of cooperative type and age on profit performance: A study of cooperative societies in Awka North LGA in Anambra State, Nigeria. African Research Review, 10(5), 187-203

Oluyombo, O. O. (2013). Household Assets and Rural Finance in Nigeria. Applied Economics Journal, 20(2), 55-74

Perry, V. G., \& Morris, M. D. (2005). Who is in control? The role of self-perception, knowledge, and income in explaining consumer financial behavior. The Journal of Consumer Affairs, 39, 299-313.

Rahman, M.H. (2018). Mudarabah and its application in islamic finance. Asian Journal of Research in Banking and Finance, 8(6), 33-46

Riwajanti, N. I. (2019). Mosque-based islamic cooperative for community economic development. Review of Integrative Business and Economics Research, 8(2), 196-208

Sherraden, M. S., \& McBride, A. M. (2010). Striving to save: Creating policies for financial security of low-income families. Ann Arbor, MI: University of Michigan Press.

Shiraj, M., Shameem, A. L. M. A., \& Nawaz, S. (2014). Comparative study on customer satisfaction of islamic and conventional banking in Sri Lanka. First International Symposium, 2014, Faculty of Islamic Studies and Arabic Language, At South Eastern University of Sri Lanka.

Sikirullahi, B. (2012). Islamic Financial Products as Alternative to Riba in the Cooperative Sector in Nigeria. Journal of Islamic Banking and Finance, 29(4), 81-112 
Tanga, T., Lemma, B.B. \& Debebe, A.D. (2019). Factors affecting saving practices of members of rural and urban saving and credit cooperatives: Evidence from Kucha Woreda, Gamo Gofa Zone, Snnprs, Ethiopia. Journal of Economics and Sustainable Development, 10(1), 10-16

\section{Copyrights}

Copyright for this article is retained by the author(s), with first publication rights granted to the journal. This is an open-access article distributed under the terms and conditions of the Creative Commons Attribution license (http://creativecommons.org/licenses/by/4.0) 